\title{
Adaptation in the visual cortex: a case for probing neuronal populations with natural stimuli [version 1; peer review: 4
}

\section{approved]}

\author{
Michoel Snow1,2, Ruben Coen-Cagli (iD1,2, Odelia Schwartz (i)3 \\ ${ }^{1}$ Department of Neuroscience, Albert Einstein College of Medicine, Bronx, NY, 10461, USA \\ ${ }^{2}$ Department of Systems and Computational Biology, Albert Einstein College of Medicine, Bronx, NY, 10461, USA \\ ${ }^{3}$ Department of Computer Science, University of Miami, Coral Gables, FL, 33146, USA
}

V1 First published: 27 Jul 2017, 6(F1000 Faculty Rev):1246

https://doi.org/10.12688/f1000research.11154.1

Latest published: 27 Jul 2017, 6(F1000 Faculty Rev):1246

https://doi.org/10.12688/f1000research.11154.1

\section{Abstract}

The perception of, and neural responses to, sensory stimuli in the present are influenced by what has been observed in the past-a phenomenon known as adaptation. We focus on adaptation in visual cortical neurons as a paradigmatic example. We review recent work that represents two shifts in the way we study adaptation, namely (i) going beyond single neurons to study adaptation in populations of neurons and (ii) going beyond simple stimuli to study adaptation to natural stimuli. We suggest that efforts in these two directions, through a closer integration of experimental and modeling approaches, will enable a more complete understanding of cortical processing in natural environments.

\section{Keywords}

visual cortical neurons, visual adaptation, natural scenes, population coding

\section{Open Peer Review \\ Approval Status \\ 1 \\ 2 \\ 3 \\ 4 \\ version 1 \\ 27 Jul 2017 \\ Faculty Reviews are review articles written by the prestigious Members of Faculty Opinions. The articles are commissioned and peer reviewed before publication to ensure that the final, published version is comprehensive and accessible. The reviewers who approved the final version are listed with their names and affiliations.}

1. Stephen A Engel, Department of Psychology, University of Minnesota, MN, USA

2. Colin WG Clifford, UNSW Sydney, Sydney, Australia

3. Nathan Crowder, Dalhousie University, Halifax, Canada

4. József Fiser, Department of Cognitive Science, Central European University, Budapest, Budapest, Hungary

Any comments on the article can be found at the 
end of the article.

Corresponding author: Odelia Schwartz (odelia@cs.miami.edu)

Competing interests: The authors declare that they have no competing interests.

Grant information: The author(s) declared that no grants were involved in supporting this work.

Copyright: @ 2017 Snow M et al. This is an open access article distributed under the terms of the Creative Commons Attribution License, which permits unrestricted use, distribution, and reproduction in any medium, provided the original work is properly cited.

How to cite this article: Snow M, Coen-Cagli $R$ and Schwartz $O$. Adaptation in the visual cortex: a case for probing neuronal populations with natural stimuli [version 1; peer review: 4 approved] F1000Research 2017, 6(F1000 Faculty Rev):1246 https://doi.org/10.12688/f1000research.11154.1

First published: 27 Jul 2017, 6(F1000 Faculty Rev):1246 https://doi.org/10.12688/f1000research.11154.1 


\section{Introduction}

Visual adaptation, hereon simply referred to as adaptation, is the influence of past visual stimuli on the responses of neurons and on perception of the present. Though adaptation was first identified millennia ago $^{1}$, its principles and functional role are still not well understood.

The earliest experimental studies of neuronal-level adaptation effects used simple, artificial stimuli repeated over time, such as oriented bars and moving dots, a technique still commonly used. Simple repetitive stimuli such as these can result in striking perceptual after-effects. For instance, in the tilt after-effect, prolonged exposure to a particular orientation of a grating results in systematic biases in perception of the orientation of another grating presented later in time ${ }^{2}$. Adaptation to stimulus features such as orientation and contrast can notably change the gain and tuning properties of neurons in early cortex as well as other response properties. These phenomena have been reviewed previously (see e.g. 3-8). Here, we also start from this class of adaptation phenomena because they provide the springboard for the more recent developments that are the focus of this review. We then identify ways in which these effects are being reinterpreted and extended within the context of natural scenes and neuronal populations.

While we have gained considerable knowledge with the classical approach, it has some important limitations. First, adaptation effects are not limited to low-level image features such as orientation and contrast, as they have also been observed for higher-level visual content such as facial expression and for complex stimuli such as natural scenes ${ }^{9,10}$, with some studies focusing on influences across the cortical hierarchy (see e.g. 11). Furthermore, as compared to artificial stimuli, the visual inputs we receive from the natural environment have more complex temporal dynamics; for instance, we may view dynamically changing images in a given location $^{12}$ or entirely new scene structure owing to eye movements. Second, most experiments have probed adaptation in single neurons ${ }^{8}$. Visual processing, however, relies on populations of neurons, and circuit-level effects of adaptation are poorly understood (but see recent progress ${ }^{13-18}$ ). As a consequence, we have a limited understanding of what aspects of neural adaptation are responsible for the observed perceptual effects, as we illustrate below. Third, computationally, despite recent advances ${ }^{19-25}$, we still lack a comprehensive model that can predict when adaptation will be recruited for arbitrary, natural stimuli or the degree to which it will occur. More generally, the link between the observable effects and the functional goals of adaptation has been elusive.

One promising approach to address these issues is based on the assumption that neural systems are sensitive to the statistical structure of stimuli in the natural environment over space and time and that adaptation reflects these statistics ${ }^{6,7,26-32}$. According to this view, to more fully understand and accurately model adaptation would require studying neural systems exposed to the natural environment. Here, we review recent literature that is taking studies of adaptation in exciting new directions, focusing on new experiments, analyses, and models that (i) are going beyond the single-neuron level and tapping into the neuronal population level and (ii) are using naturalistic scenes in lieu of simple, artificial stimuli.
For recent reviews covering other aspects of visual adaptation, such as timescales of adaptation, effects outside of the classical receptive field, inheritance across multiple stages of neural processing, potential neural mechanisms, and compensation for biological variation, see 8,33 . Adaptation may also be related to forms of plasticity that take place on different timescales such as perceptual learning and developmental processes, and studies of adaptation have extended beyond the traditional sensory domains to systems such as memory and action ${ }^{34-39}$. Although beyond the scope of this review, we believe that the framework that is emerging from the more limited set of studies we discuss here on natural scenes and population coding could, in the future, provide a conceptual bridge to those aforementioned domains.

\section{Adaptation in neuronal populations}

Most neurophysiology studies of adaptation have focused on single neurons-more specifically, examining the average neural response across repeated trials of the same stimulus condition ${ }^{8}$. However, some adaptation effects are revealed only by analyzing the activity of populations of neurons. For example, Benucci et al..$^{40}$ demonstrated a form of homeostasis across the neuronal population while recording simultaneously from tens of neurons. They adapted the population to a biased stimulus ensemble in which some orientations were presented more frequently than others. They found that after adaptation, despite the stimulus bias, neurons with different orientation preferences, on average, had the same response level across the ensemble. Such population data offer a richer test bed for models of adaptation ${ }^{19,20}$ and have the potential to link to perceptual phenomena.

Here we focus, in particular, on adaptation as it affects the variability of neural activity. It is well known that neural responses fluctuate substantially across trials ${ }^{41,42}$ and that such fluctuations are shared between neurons, as quantified by "noise correlations" ${ }^{43}$. This variability can strongly influence information in neuronal populations and, ultimately, perception ${ }^{4-51}$. The structure and stimulus dependence of cortical variability have been thoroughly characterized ${ }^{52-58}$, and recent studies have begun to examine how it is affected by adaptation.

Benucci et al ${ }^{40}$ reported that, in their experimental paradigm, adaptation did not affect the overall level of noise correlations. The adapted neurons exposed to the biased stimulus ensemble maintained the same degree of average correlation as the unadapted neurons did to the uniform stimulus ensemble, regardless of the similarity between the preferred orientation of the neurons and the biased orientation. This result was at odds with a previous study ${ }^{59}$ based on the traditional adaptation paradigm of prolonged exposure to a single stimulus (a grating with fixed orientation, as opposed to a biased ensemble). Gutnisky et al..$^{59}$ reported an overall reduction of noise correlations in primary visual cortex (V1) after adaptation. The strength of the reduction depended on the relative orientation preference of the neurons and the orientation of the adapter. They also speculated that these effects could increase population information about stimulus orientation.

A more recent study has also reported evidence for decorrelation ${ }^{60}$, primarily for pairs of neurons in marmoset middle temporal visual 
area (MT), whose preferred direction of visual motion was similar to the adaptor. The authors took a more direct approach to assessing the consequences of adaptation for population information. They used a decoding-based analysis to read out, on a trial-by-trial basis, the direction encoded by the population. They found no impact of adaptation on decoder performance, i.e. no change in the percentage of cases where the decoder's output matched the true test direction. However, the distribution of errors was asymmetri$\mathrm{cal}$, and the decoder was on average biased in a manner consistent with the perceptual direction after-effect ${ }^{61,62}$, i.e. the decoded direction was repelled away from the true direction by up to 5 degrees when the adapter was around 60 degrees away from the test. Zavitz et al. ${ }^{60}$ also found that noise correlations had a minimal effect on the decoder's performance; the direction after-effect was attributed mainly to the effects of adaptation on response gain, consistent with previous models in the temporal ${ }^{7}$ and spatial ${ }^{63,64}$ domains. Another recent study ${ }^{65}$ has focused on population-level adaptation in rat barrel cortex, reporting that adaptation generally increases noise correlations but increases single-neuron information even more. The net effect is that adaptation increases information at the population level around the adapter.

The heterogeneity of effects reported in these studies is indicative of a number of caveats that should be considered when studying population coding. For instance, the conclusion of Gutnisky et al..$^{59}$, that adaptation increases information, was based on simulating populations with artificially constructed tuning curves and covariances, a method that is prone to mis-estimation of information ${ }^{49,51}$. Benucci et $a l .{ }^{40}$ analyzed noise correlations only at a coarse level, and it is possible that a decoding-based approach could reveal a role of noise correlations despite their relatively small change, on average, across the population. The decoder-based analysis of Zavitz et al. ${ }^{60}$ and Adibi et al. ${ }^{65}$ is a safer route to address the effects of adaptation on stimulus discrimination performance; however, it has recently become clear that correlations may have a substantially different impact on information for small populations of few tens of neurons versus larger populations with size comparable to the number of neurons presumably involved in solving the perceptual $\operatorname{task}^{51}$. It is also important to keep in mind that decoding is always task dependent and conclusions drawn from decoding-based analyses are specific to the task considered (e.g. discrimination of visual orientation in V1 or motion direction in MT). Adaptation-induced changes in the population code may have different functional relevance when considering different tasks or computational goals, a point we explore further below.

The field clearly needs a much more extensive and systematic study of population-level adaptation and its relation to perception. We suggest that this effort could benefit from leveraging recent developments in the broader field of neuronal population coding: 1) simultaneous recording from larger populations of hundreds (which is feasible with current technology ${ }^{53}$ ) or thousands of neurons (which might soon become feasible ${ }^{66}$ ), 2) decoding-based analysis of population data, which is becoming commonplace in other studies of visual processing besides adaptation ${ }^{49,67-70}$ (please see 47,71 for broader reviews on population decoding), and 3) theories of population coding in the context of well-specified computational goals ${ }^{72,73}$. While this section has focused on the first two elements above, in the next section we discuss recent proposals for the computational goals of adaptation that go beyond discrimination tasks with simple stimuli.

\section{Adaptation to natural scenes}

While we have learned a lot from studying adaptation to simple stimuli, and these continue to be useful as benchmarks for systematic manipulation, replication, and comparison, there has been growing interest in understanding adaptation for more naturalistic stimuli. This interest is because of the difficulty in extrapolating from simple stimuli how the brain adapts to stimuli it encounters in the natural environment. There is also reason to expect that aspects of neural responses are tuned to the properties of the visual environment, as has been demonstrated in many areas of visual processing $26,29,32,74,75$. Some studies have pushed forward the hypothesis that neural properties are constrained by task-related goals: for example, Burge and Geisler ${ }^{76}$ used natural scenes to develop an ideal observer for speed estimation and showed that this closely matched human performance. Other studies have focused on deriving models of visual neurons with task-independent goals, such as efficient coding. In this section, we first discuss the use of natural stimuli in experimental paradigms of adaptation. We then discuss computational models of adaptation motivated by the structure of visual scenes. Finally, we note new techniques which potentially can be applied to adaptation in the near future.

Many studies of adaptation have focused on synthetic stimuli owing to the inherent complexity of natural stimuli and the difficulty of parsing specific aspects of these stimuli to create controlled experiments ${ }^{28}$. Recently, there has been a trend of experimental design using more naturalistic stimuli, with the main focus on using static natural images ${ }^{77-82}$. The use of natural stimuli can often provide similar benchmarks to synthetic stimuli. For example, the perceptual tilt after-effect seen with synthetic stimuli is still observed with natural images (chosen according to their dominant orientation), but to a lesser degree ${ }^{77,78}$. Repulsive adaptation effects have also been studied for faces and have been reported for higher-level properties such as openness of the scene ${ }^{9,83}$. Taking a different approach, in an elegant reversal of the conventional design, instead of starting from a gray screen and then testing the effect of adapting to an oriented contrast grating, Haak et al. ${ }^{84}$ used an alternate reality system to remove an orientation from subjects' otherwise natural visual input, continuously, over multiple days. The overall strength of the adaptive effects peaked after the first day, then declined, but increased again more slowly as the days progressed. Each of their testing paradigms had its own set of peaks and troughs, with the strength of effects changing within individual sessions and across progressive days. They concluded that the variations in adaptive effects were due to multiple neural mechanisms operating at different time scales, in line with their earlier work ${ }^{85}$ and related to results seen for synthetic stimuli (for review, see 8).

Computational models have also started to incorporate more aspects of natural scenes. We first discuss theoretical approaches for modeling the functional role of adaptation. We then focus on how the form and parameters of such models may be constrained and learned from natural scenes. One early hypothesis was that 
adaptation implements efficient coding principles (see, for example, the discussion in 4,7). Examples of this perspective range from a reduction of metabolic $\operatorname{cost}^{86}$ to improved signal-tonoise ratio $^{22}$, enhanced information transmission ${ }^{87,88}$, redundancy reduction ${ }^{19,23,25,26,75,89}$, and complementary directions of probabilistic inference in generative models of the environment ${ }^{20,24}$. Foundational work has related changes in V1 population-level activity over long time scales (development) to learning a well-calibrated prior for natural stimuli ${ }^{36}$. Along with other similar work, this has provided a normative framework of how response variability and noise correlations depend on features of the visual inputs ${ }^{90}$, and recent findings indicate that a similar approach could provide a new view of population-level adaptation on relatively shorter timescales (minutes to hours ${ }^{91}$ ).

Another hypothesis states that adaptation serves to enhance stimulus salience, which may be related to the notion of reducing redundant information. Salience has been studied extensively in the spatial context domain (e.g. 92-94). In particular, computational modeling and experimental tests have supported the hypothesis that V1 forms a salience map corresponding to the breakdown of homogeneity of the input ${ }^{92,93,95,96}$. In the temporal domain, salience may be viewed as novelty detection, postulating that adaptation serves to enhance neural responsivity to stimuli that are unexpected, e.g. stimuli that differ significantly from the adapter. This relates to ideas of predictive coding ${ }^{21}$ and to literature on the mismatch negativity in evoked potentials, which is more prominent in the auditory domain ${ }^{97-100}$. Recently, experimental groups have started to perceptually test the hypothesis that adaptation enhances saliency ${ }^{101-103}$.

In recent work, following some of our earlier approaches on spatial context modeling ${ }^{104}$, we have proposed, in the temporal domain, that adaptation effects may be explained as probabilistic inference in a generative model of the statistical dependencies in natural movies $^{20}$. In this framework, adaptation also reduces statistical redundancies that are induced by the stimuli. The redundancy reduction is achieved by adjusting the strength of a divisive normalization signal based on inference in the model about whether stimuli in the present and past are deemed statistically dependent. This constitutes a generalization of earlier work on redundancy reduction in still images and divisive normalization ${ }^{25,105}$, and relates to previous work on salience as a breakdown of statistical homogeneity ${ }^{93}$.

Divisive normalization refers to a non-linear computation, whereby the response of a given neural unit is divided by the activity of other neural units ${ }^{106}$. It has been termed a canonical computation in cortex ${ }^{107}$ and has been shown to be consistent with adaptation phenomena in a range of other cortical areas, such as the auditory cortex, olfactory system, visual attention, and integration of multisensory information ${ }^{4,8}$. A mechanism for divisive normalization in the context of adaptation has been proposed recently, in which adaptation adjusts the strength of the interactions between model neurons (specifically, the weights of a divisive normalization signal) to homeostatically maintain the products of responses of pairs of neurons ${ }^{19}$. Both modeling frameworks ${ }^{19,20}$ replicated aspects of the main adaptation phenomena, namely suppression and repulsion at the single-neuron level as well as equalization of population responses, and they both could explain the tilt after-effect.

However, although learned with natural scenes, the adaptation model of Snow et al. ${ }^{20}$ (as well as other models inspired by or learned with natural scenes) have typically been tested experimentally only with simple stimuli. While an important first step, simple stimuli lack the richness of natural stimuli, with which such models are learned. This constitutes a limitation not only for testing our models but also, more broadly, when a variety of cortical properties appear to be attuned to the inherent properties of natural scenes ${ }^{76,108}$. Testing computational models with natural stimuli offers a much richer test set. More importantly, one can study neural or perceptual responses to natural stimuli in the context of the computational models and their predictions.

Testing computational models derived from natural scenes with natural scene stimuli has been emerging in other domains. For instance, in studying spatial (rather than temporal) context effects, Coen-Cagli et al. ${ }^{109}$ derived a model of V1 from the statistics of static natural scenes. Using probabilistic inference in a generative model of spatial dependencies in images, the model made the specific prediction that when visual inputs to the receptive field center and surround of a neuron were deemed statistically dependent according to the model, this resulted in more recruitment of surround suppression to reduce the dependency. Through close interplay between the modeling and neurophysiology experiments using natural scenes in V1, this study suggested that surround suppression in cortical neurons is gated by the statistical similarity of center and surround stimuli. These directions can be extended to adaptation models and to more natural stimuli for adaptation, such as movies that incorporate motion in the environment and eye movements. There is also the potential to extend such approaches to perceptual studies (e.g. in the spatial domain ${ }^{110}$ ).

We have thus far focused largely on unsupervised learning in natural scenes and how such approaches may be used to build and test models of adaptation in early cortex. There are also other potential routes to modeling neural adaptation based on learning with natural scenes. Recently, there have been exciting advances in an area of machine learning known as deep convolutional neural networks. Deep convolutional neural networks consist of a hierarchy of layers that learn progressively more complex structure in images, inspired by the hierarchical organization in the visual cortex. Recent advances in the field have focused on supervised task-based learning approaches that discriminate between a large ensemble of labeled images. Modern versions of deep convolutional neural networks have led to state-of-the-art results in scene recognition in computer vision ${ }^{111,112}$. These approaches have in turn been recently applied within the neuroscience community, with the goal of capturing cortical processing in higher visual areas, beyond V1. There has been some indication of success relative to previous approaches $^{113-116}$.

These approaches have not yet been used to model cortical adaptation, but we believe there is potential. To address adaptation, one would need to consider how learning in deep neural network models is updated over time as the network is exposed to new 
stimuli. We believe there are two potential routes for achieving this, both of which require extending the deep neural network framework. One approach includes adding recurrent connections that are updated over time. This form of model has interestingly been shown to be effective for modeling contrast adaptation of retinal neurons to natural scenes ${ }^{117}$. A second approach includes adding divisive normalization to deep neural network models. Divisive normalization is already present in simple forms in deep convolutional neural networks (see e.g. references in 37,118). One would need to extend such models to incorporate adaptation in time. We should emphasize that the potential of incorporating adaptation into deep neural networks is not limited to supervised discriminative networks. There has also been recent progress in building unsupervised deep convolutional networks with divisive normalization (e.g. 119). Deep convolutional networks together with more plausible nonlinearities may provide a means of modeling adaptation in cortical neural areas beyond V1 but will ultimately need to be tested against experimental data.

In summary, simple stimuli were the starting point for studying the visual system and have taught us much over the past 50-plus years, but, as a field, our focus should shift to more complex stimuli. We suggest that experiments and models focus on using natural stimuli for both learning and testing for two reasons: 1) the greater complexity in natural inputs as compared to simple stimuli will increase our understanding of how the visual cortex deals with this complexity, potentially leading to the discovery of new phenomena, and 2) a better understanding of how cortex processes natural images could potentially equip us with more powerful tools for computer vision.

\section{Summary}

Our ability to record and predict neuronal and perceptual responses has improved dramatically over the last few years. We are able to record from more neurons simultaneously, using more complex stimuli, over longer periods of time. As we have elucidated more and more about how adaptation occurs, this has informed our understanding of the properties of adaptation. In parallel developments, theory has helped formulate hypotheses for the functional role of adaptation. In sum, it is our hope that increased capabilities for studying visual cortex at the population level, and with more naturalistic stimuli, combined with the interplay with modeling approaches, will help move forward our understanding of adaptation and its functional goals.

\section{Competing interests}

The authors declare that they have no competing interests.

Grant information

The author(s) declared that no grants were involved in supporting this work.
1. Aristotle On Dreams. In: The works of Aristotle translated into English under the editorship of W.D. Ross. Oxford University Press.

2. Gibson JJ, Radner M: Adaptation, after-effect and contrast in the perception of tilted lines. I. Quantitative studies. Journal of experimental psychology. 1937; 20(5): 453-467.

Publisher Full Text

3. Clifford CW, Rhodes G: Fitting the Mind to the World: Adaptation and AfterEffects in High-Level Vision. Oxford University Press; 2005. Publisher Full Text

4. Kohn A: Visual adaptation: physiology, mechanisms, and functional benefits. J Neurophysiol. 2007; 97(5): 3155-64.

PubMed Abstract | Publisher Full Text

5. Krekelberg B, Boynton GM, van Wezel RJ: Adaptation: from single cells to BOLD signals. Trends Neurosci. 2006; 29(5): 250-6.

PubMed Abstract | Publisher Full Text

6. Clifford CW, Webster MA, Stanley GB, et al:: Visual adaptation: neural, psychological and computational aspects. Vision Res. 2007; 47(25): 3125-31. PubMed Abstract | Publisher Full Text

7. Schwartz O, Hsu A, Dayan P: Space and time in visual context. Nat Rev Neurosci. 2007; 8(7): 522-35.

PubMed Abstract | Publisher Full Text

8. F Solomon SG, Kohn A: Moving sensory adaptation beyond suppressive effects in single neurons. Curr Biol. 2014; 24(20): R1012-22. PubMed Abstract | Publisher Full Text | Free Full Text | F1000 Recommendation

9. F Greene MR, Oliva A: High-level aftereffects to global scene properties. J Exp Psychol Hum Percept Perform. 2010; 36(6): 1430-42. PubMed Abstract | Publisher Full Text | F1000 Recommendation

10. Webster MA: Adaptation and visual coding. J Vis. 2011; 11(5): pii: 3. PubMed Abstract | Publisher Full Text | Free Full Text

11. $\mathrm{Xu} \mathrm{H}$, Liu $\mathrm{P}$, Dayan $\mathrm{P}$, et al:: Multi-level visual adaptation: dissociating curvature and facial-expression aftereffects produced by the same adapting stimuli.
Vision Res. 2012; 72: 42-53.

PubMed Abstract | Publisher Full Text

12. Weiss $\mathrm{Y}$, Adelson $\mathrm{EH}$ : Slow and smooth: $\mathrm{A}$ Bayesian theory for the combination of local motion signals in human vision. MIT Al Labs A.I. Memo 1624; 1998. Reference Source

13. Dhruv NT, Carandini M: Cascaded effects of spatial adaptation in the early visual system. Neuron. 2014; 81(3): 529-35.

PubMed Abstract | Publisher Full Text | Free Full Text

14. Musall S, von der Behrens W, Mayrhofer JM, et al: Tactile frequency discrimination is enhanced by circumventing neocortical adaptation. $N$ at Neurosci. 2014; 17(11): 1567-73. PubMed Abstract | Publisher Full Text

15. F King JL, Lowe MP, Stover KR, et al:: Adaptive Processes in Thalamus and Cortex Revealed by Silencing of Primary Visual Cortex during Contrast Adaptation. Curr Biol. 2016; 26(10): 1295-300. PubMed Abstract | Publisher Full Text | F1000 Recommendation

16. Teich $\mathrm{AF}$, Qian N: Learning and adaptation in a recurrent model of $\mathbf{V} \mathbf{1}$ orientation selectivity. J Neurophysiol. 2003; 89(4): 2086-100. PubMed Abstract | Publisher Full Text

17. $\mathrm{F}$ Makino $\mathrm{H}$, Hwang EJ, Hedrick NG, et al.: Circuit Mechanisms of Sensorimotor Learning. Neuron. 2016; 92(4): 705-21. PubMed Abstract | Publisher Full Text | Free Full Text | F1000 Recommendation

18. F Quiroga M, Morris AP, Krekelberg B: Adaptation without Plasticity. Cell Rep. 2016; 17(1): 58-68.

PubMed Abstract | Publisher Full Text | Free Full Text | F1000 Recommendation

19. F Westrick ZM, Heeger DJ, Landy MS: Pattern Adaptation and Normalization Reweighting. J Neurosci. 2016; 36(38): 9805-16. PubMed Abstract | Publisher Full Text | Free Full Text | F1000 Recommendation

20. Snow M, Coen-Cagli R, Schwartz O: Specificity and timescales of cortical 
adaptation as inferences about natural movie statistics. J Vis. 2016; 16(13). PubMed Abstract | Publisher Full Text | Free Full Text

21. Lochmann $T$, Ernst UA, Denève $S$ : Perceptual inference predicts contextual modulations of sensory responses. J Neurosci. 2012; 32(12): 4179-95. PubMed Abstract | Publisher Full Text

22. Stocker A, Simoncelli EP: Sensory adaptation within a Bayesian framework for perception. Adv Neural Inf Process Syst. 2006; 18: 1291-1298. Reference Source

23. Barlow H, Földiák P: Adaptation and decorrelation in the cortex. In: Durbin $\mathrm{R}$, Miall $\mathrm{C}$, and Mitchison G eds. The Computing neuron. Wokingham, England. Addison-Wesley Pub. Co., 1989; 54-72.

Reference Source

24. Dayan P, Sahani M, Deback G: Adaptation and Unsupervised Learning. In: Becker S, Thrun S, and Obermayer K eds. Advances in Neural Information Processing Systems 15. MIT Press, 2002; 237-244. Reference Source

25. Wainwright $M$, Schwartz $O$, Simoncelli E: Natural image statistics and divisive normalization: Modeling nonlinearity and adaptation in cortical neurons. In: Rao R, Olshausen, B Lewicki M eds. Probabilistic models of the brain: Perception and neural function. Cambridge, Mass: MIT Press, 2002; 203-222. Reference Source

26. Barlow H: Possible Principles Underlying the Transformation of Sensory Messages. In: Rosenblith W A ed. Sensory communication. MIT Press, 1961 217-234.

Reference Source

27. Olshausen B, Field D: Vision and the coding of natural images. American Scientist. 2000; 88(3): 238

Publisher Full Text

28. Rieke F, Rudd ME: The challenges natural images pose for visual adaptation. Neuron 2009; 64(5): 605-16.

PubMed Abstract | Publisher Full Tex

29. Simoncelli EP, Olshausen BA: Natural image statistics and neural representation. Annu Rev Neurosci. 2001; 24: 1193-216.

PubMed Abstract | Publisher Full Text

30. Wark B, Lundstrom BN, Fairhall A: Sensory adaptation. Curr Opin Neurobiol. 2007; 17(4): 423-9.

PubMed Abstract | Publisher Full Text | Free Full Text

31. Hyvärinen A: Statistical models of natural images and cortical visual representation. Top Cogn Sci. 2010; 2(2): 251-64.

PubMed Abstract | Publisher Full Text

32. Geisler WS: Visual perception and the statistical properties of natural scenes. Annu Rev Psychol. 2008; 59: 167-92. PubMed Abstract | Publisher Full Text

33. F Webster MA: Visual Adaptation. Annu Rev Vis Sci. 2015; 1: 547-67. PubMed Abstract | Publisher Full Text | Free Full Text | F1000 Recommendation

34. Sagi D: Perceptual learning in Vision Research. Vision Res. 2011; 51(13): 1552-66. PubMed Abstract | Publisher Full Text

35. Wolpert DM, Diedrichsen J, Flanagan JR: Principles of sensorimotor learning Nat Rev Neurosci. 2011; 12(12): 739-751.

PubMed Abstract | Publisher Full Text

36. Berkes $\mathrm{P}$, Orbán $\mathrm{G}$, Lengyel $\mathrm{M}$, et al:: Spontaneous cortical activity reveals hallmarks of an optimal internal model of the environment. Science. 2011; 331(6013): 83-7.

PubMed Abstract | Publisher Full Text | Free Full Text

37. Schwartz O, Giraldo LG: Behavioral and neural constraints on hierarchical representations. J Vis. 2017; 17(3): 13 PubMed Abstract | Publisher Full Text

38. Jacobs RA: Integrated approaches to perceptual learning. Top Cogn Sci. 2010; 2(2): 182-8.

PubMed Abstract | Publisher Full Text

39. Kwon O, Knill DC: The brain uses adaptive internal models of scene statistics for sensorimotor estimation and planning. Proc Natl Acad Sci U S A. 2013; 110(11): E1064-73.

PubMed Abstract | Publisher Full Text | Free Full Text

40. F Benucci A, Saleem AB, Carandini M: Adaptation maintains population homeostasis in primary visual cortex. Nat Neurosci. 2013; 16(6): 724-9. PubMed Abstract | Publisher Full Text | Free Full Text | F1000 Recommendation

41. Tolhurst DJ, Movshon JA, Dean AF: The statistical reliability of signals in single neurons in cat and monkey visual cortex. Vision Res. 1983; 23(8): 775-785. PubMed Abstract | Publisher Full Text

42. Goris RL, Movshon JA, Simoncelli EP: Partitioning neuronal variability. Nat Neurosci. 2014; 17(6): 858-65. PubMed Abstract | Publisher Full Text | Free Full Text

43. F Cohen MR, Kohn A: Measuring and interpreting neuronal correlations Nat Neurosci. 2011; 14(7): 811-9.

PubMed Abstract | Publisher Full Text | Free Full Text | F1000 Recommendation

44. Zohary E, Shadlen MN, Newsome WT: Correlated neuronal discharge rate and its implications for psychophysical performance. Nature. 1994; 370(6485): $140-3$.

PubMed Abstract | Publisher Full Text

45. Abbott LF, Dayan P: The effect of correlated variability on the accuracy of a population code. Neural Comput. 1999; 11(1): 91-101. PubMed Abstract | Publisher Full Text
46. Sompolinsky H, Yoon $\mathrm{H}$, Kang K, et al.: Population coding in neuronal systems with correlated noise. Phys Rev E Stat Nonlin Soft Matter Phys. 2001; 64(5 Pt 1): 051904

PubMed Abstract | Publisher Full Text

47. Averbeck BB, Latham PE, Pouget A: Neural correlations, population coding and computation. Nat Rev Neurosci. 2006; 7(5): 358-66.

PubMed Abstract | Publisher Full Text

48. F Cohen MR, Maunsell JH: Attention improves performance primarily by reducing interneuronal correlations. Nat Neurosci. 2009; 12(12): 1594-600. PubMed Abstract | Publisher Full Text | Free Full Text | F1000 Recommendation

49. Moreno-Bote R, Beck J, Kanitscheider I, et al.: Information-limiting correlations. Nat Neurosci. 2014; 17(10): 1410-7. PubMed Abstract | Publisher Full Text | Free Full Text

50. Kanitscheider I, Coen-Cagli R, Pouget A: Origin of information-limiting noise correlations. Proc Natl Acad Sci U S A. 2015; 112(50): E6973-82. PubMed Abstract | Publisher Full Text | Free Full Text

51. Kohn A, Coen-Cagli R, Kanitscheider I, et al.: Correlations and Neuronal Population Information. Annu Rev Neurosci. 2016; 39: 237-56. PubMed Abstract | Publisher Full Text | Free Full Text

52. Arieli A, Sterkin A, Grinvald A, et al:: Dynamics of ongoing activity: explanation of the large variability in evoked cortical responses. Science. 1996; 273(5283): $1868-71$.

PubMed Abstract | Publisher Full Tex

53. $F$ Kohn A, Smith MA: Stimulus dependence of neuronal correlation in primary visual cortex of the macaque. J Neurosci. 2005; 25(14): 3661-73. PubMed Abstract | Publisher Full Text | F1000 Recommendation

54. F Smith MA, Kohn A: Spatial and temporal scales of neuronal correlation in primary visual cortex. J Neurosci. 2008; 28(48): 12591-603. PubMed Abstract | Publisher Full Text | Free Full Text | F1000 Recommendation

55. F Ponce-Alvarez A, Thiele A, Albright TD, et al.: Stimulus-dependent variability and noise correlations in cortical MT neurons. Proc Natl Acad Sci U S A. 2013; 110(32): 13162-7.

PubMed Abstract | Publisher Full Text | Free Full Text | F1000 Recommendation

56. Ecker AS, Berens $P$, Cotton RJ, et al:: State dependence of noise correlations in macaque primary visual cortex. Neuron. 2014; 82(1): 235-48. PubMed Abstract | Publisher Full Text | Free Full Text

57. Scholvinck ML, Saleem AB, Benucci A, et al:: Cortical state determines global variability and correlations in visual cortex. J Neurosci. 2015; 35(1): 170-8. PubMed Abstract | Publisher Full Text | Free Full Text

58. Okun M, Steinmetz N, Cossell L, et al.: Diverse coupling of neurons to populations in sensory cortex. Nature. 2015; 521(7553): 511-5. PubMed Abstract | Publisher Full Text | Free Full Text

59. F Gutnisky DA, Dragoi V: Adaptive coding of visual information in neural populations. Nature. 2008; 452(7184): 220-224. PubMed Abstract | Publisher Full Text | F1000 Recommendation

60. F Zavitz E, Yu HH, Rowe EG, et al:: Rapid Adaptation Induces Persistent Biases in Population Codes for Visual Motion. J Neurosci. 2016; 36(16): 4579-90. PubMed Abstract | Publisher Full Text | F1000 Recommendation

61. Levinson E, Sekuler R: Adaptation alters perceived direction of motion. Vision Res. 1976; 16(7): 779-781. PubMed Abstract | Publisher Full Tex

62. Clifford CW, Wenderoth $\mathrm{P}$, Spehar B: A functional angle on some after-effects in cortical vision. Proc Biol Sci. 2000; 267(1454): 1705-10. PubMed Abstract | Publisher Full Text | Free Full Text

63. Schwartz O, Sejnowski TJ, Dayan P: Perceptual organization in the tilt illusion J Vis. 2009; 9(4): 19.1-20. PubMed Abstract | Publisher Full Text | Free Full Text

64. Coen--cagli R, Dayan P, Schwartz O: Statistical Models of Linear and Nonlinear Contextual Interactions in Early Visual Processing. In: Bengio Y, Schuurmans D, Lafferty JD, Williams CKI, Culotta A. eds. Advances in Neural Information Processing Systems 22. Curran Associates, Inc., 2009; 369-377. Reference Source

65. Adibi M, McDonald JS, Clifford CW, et al.: Population decoding in rat barre cortex: optimizing the linear readout of correlated population responses. PLoS Comput Biol. 2014; 10(1): e1003415. PubMed Abstract | Publisher Full Text | Free Full Text

66. Jorgenson LA, Newsome WT, Anderson DJ, et al:: The BRAIN Initiative: developing technology to catalyse neuroscience discovery. Philos Trans $R$ Soc Lond B Biol Sci. 2015; 370(1668): pii: 20140164 PubMed Abstract | Publisher Full Text | Free Full Text

67. F Chen Y, Geisler WS, Seidemann E: Optimal decoding of correlated neural population responses in the primate visual cortex. Nat Neurosci. 2006; 9(11): 1412-20.

PubMed Abstract | Publisher Full Text | Free Full Text | F1000 Recommendation

68. Graf $A B$, Kohn A, Jazayeri M, et al.: Decoding the activity of neuronal populations in macaque primary visual cortex. Nat Neurosci. 2011; 14(2): 239-45.

PubMed Abstract | Publisher Full Text | Free Full Text

69. Berens $\mathrm{P}$, Ecker AS, Cotton RJ, et al:: $\mathbf{A}$ fast and simple population code for orientation in primate V1. J Neurosci. 2012; 32(31): 10618-26. PubMed Abstract | Publisher Full Text | Free Full Text 
70. Arandia-Romero I, Tanabe S, Drugowitsch J, et al:: Multiplicative and Additive Modulation of Neuronal Tuning with Population Activity Affects Encoded Information. Neuron. 2016; 89(6): 1305-16.

PubMed Abstract | Publisher Full Text | Free Full Tex

71. Quian Quiroga R, Panzeri S: Extracting information from neuronal populations: information theory and decoding approaches. Nat Rev Neurosci. 2009; 10(3): 173-85.

PubMed Abstract | Publisher Full Text

72. F Ma WJ, Beck JM, Latham PE, et al:: Bayesian inference with probabilistic population codes. Nat Neurosci. 2006; 9(11): 1432-8. PubMed Abstract | Publisher Full Text | F1000 Recommendation

73. Fiser J, Berkes $P$, Orbán G, et al:: Statistically optimal perception and learning: from behavior to neural representations. Trends Cogn Sci. 2010; 14(3): 119-30. PubMed Abstract | Publisher Full Text | Free Full Text

74. Zhaoping L: Theoretical understanding of the early visual processes by data compression and data selection. Network. 2006; 17(4): 301-34. PubMed Abstract | Publisher Full Text

75. Attneave F: Some informational aspects of visual perception. Psychol Rev 1954; 61(3): 183-93.

PubMed Abstract | Publisher Full Text

76. Burge J, Geisler WS: Optimal speed estimation in natural image movies predicts human performance. Nat Commun. 2015; 6: 7900

PubMed Abstract | Publisher Full Text | Free Full Tex

77. F Dekel R, Sagi D: Tilt aftereffect due to adaptation to natural stimuli. Vision Res. 2015; 117: 91-9.

PubMed Abstract | Publisher Full Text | F1000 Recommendation

78. F Hussain Ismail AM, Solomon JA, Hansard M, et al:: A tilt after-effect for images of buildings: evidence of selectivity for the orientation of everyday scenes. $R$ Soc Open Sci. 2016; 3(11): 160551.

PubMed Abstract | Publisher Full Text | Free Full Text | F1000 Recommendation

79. Kompaniez E, Abbey CK, Boone JM, et al:: Adaptation aftereffects in the perception of radiological images. PLoS One. 2013; 8(10): e76175. PubMed Abstract | Publisher Full Text | Free Full Text

80. F Luo C, Wang Q, Schyns PG, et al:: Facial Expression Aftereffect Revealed by Adaption to Emotion-Invisible Dynamic Bubbled Faces. PLOS One. 2015; 10(12): e0145877.

PubMed Abstract | Publisher Full Text | Free Full Text | F1000 Recommendation

81. F Kaliukhovich DA, Vogels R: Divisive Normalization Predicts AdaptationInduced Response Changes in Macaque Inferior Temporal Cortex. J Neurosci. 2016; 36(22): 6116-28

PubMed Abstract | Publisher Full Text | F1000 Recommendation

82. May KA, Zhaoping L, Hibbard PB: Perceived direction of motion determined by adaptation to static binocular images. Curr Biol. 2012; 22(1): 28-32. PubMed Abstract | Publisher Full Text

83. Webster MA, MacLeod DI: Visual adaptation and face perception. Philos Trans $R$ Soc Lond B Biol Sci. 2011; 366(1571): 1702-25.

PubMed Abstract | Publisher Full Text | Free Full Text

84. Haak KV, Fast E, Bao M, et al.: Four days of visual contrast deprivation reveals limits of neuronal adaptation. Curr Biol. 2014; 24(21): 2575-9. PubMed Abstract | Publisher Full Text

85. Bao M, Fast E, Mesik J, et al.: Distinct mechanisms control contrast adaptation over different timescales. J Vis. 2013; 13(10): pii: 14 PubMed Abstract | Publisher Full Text

86. F Laughlin S: A simple coding procedure enhances a neuron's information capacity. Z Naturforsch C. 1981; 36(9-10): 910-2.

PubMed Abstract | F1000 Recommendation

87. F Sharpee TO, Sugihara $\mathrm{H}$, Kurgansky AV, et al:: Adaptive filtering enhances information transmission in visual cortex. Nature. 2006; 439(7079): 936-42. PubMed Abstract | Publisher Full Text | Free Full Text | F1000 Recommendation

88. Wainwright MJ: Visual adaptation as optimal information transmission. Vision Res. 1999; 39(23): 3960-3974.

PubMed Abstract | Publisher Full Text

89. Atick JJ, Li Z, Redlich AN: What does post--adaptation color appearance revea about cortical color representation? Vision Res. 1993; 33(1): 123-129. PubMed Abstract | Publisher Full Tex

90. F Orbán G, Berkes P, Fiser J, et al:: Neural Variability and Sampling-Based Probabilistic Representations in the Visual Cortex. Neuron. 2016; 92(2): 530-43. PubMed Abstract | Publisher Full Text | Free Full Text | F1000 Recommendation

91. Orbán G, Stippiner M, Lazar A, et al:: Adaptation of spontaneous activity in V1 during exposure to a novel stimulus statistics. In: COSYNE. Abstracts. Salt Lake City, USA. 2017.

92. Li Z: A saliency map in primary visual cortex. Trends Cogn Sci. 2002; 6(1): 9-16. PubMed Abstract | Publisher Full Text

93. Li Z: Visual segmentation by contextual influences via intra-cortical interactions in the primary visual cortex. Network. 1999; 10(2): 187-212. PubMed Abstract | Publisher Full Text

94. Itti L, Koch C, Niebur E: A model of saliency--based visual attention for rapid scene analysis. IEEE Trans Pattern Anal Mach Intell. 1998; 20(11): 1254-1259. Publisher Full Text
95. F Zhaoping L, Zhe L: Primary Visual Cortex as a Saliency Map: A ParameterFree Prediction and Its Test by Behavioral Data. PLOS Comput Biol. 2015; 11(10): e1004375

PubMed Abstract | Publisher Full Text | Free Full Text | F1000 Recommendation

96. Zhaoping L: Understanding vision: theory, models, and data. Oxford University

Press. 2014

Publisher Full Text

97. Näätänen R, Tervaniemi M, Sussman E, et al:: "Primitive intelligence" in the auditory cortex. Trends Neurosci. 2001; 24(5): 283-288.

PubMed Abstract | Publisher Full Text

98. Garrido MI, Sahani M, Dolan RJ: Outlier responses reflect sensitivity to statistical structure in the human brain. PLoS Comput Biol. 2013; 9(9): e1002999. PubMed Abstract | Publisher Full Text | Free Full Text

99. Stefanics G, Kremláček J, Czigler I: Visual mismatch negativity: a predictive coding view. Front Hum Neurosci. 2014; 8: 666. PubMed Abstract | Publisher Full Text | Free Full Text

100. Symonds RM, Lee WW, Kohn A, et al:: Distinguishing Neural Adaptation and Predictive Coding Hypotheses in Auditory Change Detection. Brain Topogr. 2017; 30(1): 136-48.

PubMed Abstract | Publisher Full Text | Free Full Text

101. F McDermott KC, Malkoc G, Mulligan JB, et al:: Adaptation and visual salience. J Vis. 2010; 10(13): 17

PubMed Abstract | Publisher Full Text | Free Full Text | F1000 Recommendation

102. Wissig SC, Patterson CA, Kohn A: Adaptation improves performance on a visual search task. J Vis. 2013; 13(2): 6.

PubMed Abstract | Publisher Full Text | Free Full Text

103. Kompaniez-Dunigan E, Abbey CK, Boone JM, et al:: Adaptation and visual search in mammographic images. Atten Percept Psychophys. 2015; 77(4): 1081-7. PubMed Abstract | Publisher Full Text | Free Full Text

104. Coen-Cagli R, Dayan P, Schwartz O: Cortical Surround Interactions and Perceptual Salience via Natural Scene Statistics. PLoS Comput Biol. 2012; 8(3): e1002405.

PubMed Abstract | Publisher Full Text | Free Full Text

105. F Schwartz $O$, Simoncelli EP: Natural signal statistics and sensory gain control. Nat Neurosci. 2001; 4(8): 819-25.

PubMed Abstract | Publisher Full Text | F1000 Recommendation

106. Heeger DJ: Normalization of cell responses in cat striate cortex. Vis Neurosci. 1992; 9(2): 181-97. PubMed Abstract | Publisher Full Text

107. F Carandini M, Heeger DJ: Normalization as a canonical neural computation. Nat Rev Neurosci. 2011; 13(1): 51-62.

PubMed Abstract | Publisher Full Text | Free Full Text | F1000 Recommendation

108. D'Antona AD, Perry JS, Geisler WS: Humans make efficient use of natural image statistics when performing spatial interpolation. J Vis. 2013; 13(14): pii: 11. PubMed Abstract | Publisher Full Text | Free Full Text

109. Coen-Cagli R, Kohn A, Schwartz O: Flexible gating of contextual influences in natural vision. Nat Neurosci. 2015; 18(11): 1648-55. PubMed Abstract | Publisher Full Text | Free Full Text

110. Qu C, Kersten D, Olman CA: Segmentation decreases the magnitude of the tilt illusion. J Vis. 2013; 13(13): 19. PubMed Abstract | Publisher Full Text | Free Full Text

111. Krizhevsky A, Sutskever I, Hinton GE: Imagenet classification with deep convolutional neural networks. Adv Neural Inf Process Syst. 2012. Reference Source

112. F LeCun $Y$, Bengio $Y$, Hinton G: Deep learning. Nature. 2015; 521 (7553): 436-44. PublMed Abstract | Publisher Full Text | F1000 Recommendation

113. $\mathrm{F}$ Yamins DL, DiCarlo JJ: Using goal-driven deep learning models to understand sensory cortex. Nat Neurosci. 2016; 19(3): 356-65. PubMed Abstract | Publisher Full Text | F1000 Recommendation

114. F Kriegeskorte N: Deep Neural Networks: A New Framework for Modeling Biological Vision and Brain Information Processing. Annu Rev Vis Sci. 2015; 1 : 417-46.

PubMed Abstract | Publisher Full Text | F1000 Recommendation

115. F Cichy RM, Khosla A, Pantazis D, et al.: Comparison of deep neural networks to spatio-temporal cortical dynamics of human visual object recognition reveals hierarchical correspondence. Sci Rep. 2016; 6: 27755. PubMed Abstract | Publisher Full Text | Free Full Text | F1000 Recommendation

116. F Güçlü U, van Gerven MA: Increasingly complex representations of natural movies across the dorsal stream are shared between subjects. Neuroimage. 2017; 145(Pt B): 329-336.

PubMed Abstract | Publisher Full Text | F1000 Recommendation

117. McIntosh L, Maheswaranathan N, Nayebi A, et al.: Deep learning models of the retinal response to natural scenes. Adv Neural Inf Process Syst. 2016. Reference Source

118. Ren M, Liao R, Urtasun R, et al.: Normalizing the Normalizers: Comparing and Extending Network Normalization Schemes. arXiv preprint arXiv. 2016. Reference Source

119. Ballé J, Laparra V, Simoncelli EP: End-to-end Optimized Image Compression. arXiv preprint arXiv:1611.01704.2016.

Reference Source 


\section{Open Peer Review}

\section{Current Peer Review Status:}

\section{Editorial Note on the Review Process}

Faculty Reviews are review articles written by the prestigious Members of Faculty Opinions. The articles are commissioned and peer reviewed before publication to ensure that the final, published version is comprehensive and accessible. The reviewers who approved the final version are listed with their names and affiliations.

\section{The reviewers who approved this article are:}

\section{Version 1}

\section{József Fiser}

Department of Cognitive Science, Central European University, Budapest, Budapest, Hungary

Competing Interests: No competing interests were disclosed.

\section{Nathan Crowder}

Department of Psychology and Neuroscience, Dalhousie University, Halifax, NS, Canada

Competing Interests: No competing interests were disclosed.

\section{Colin WG Clifford}

UNSW Sydney, Sydney, Australia

Competing Interests: No competing interests were disclosed.

\section{Stephen A Engel}

Department of Psychology, University of Minnesota, MN, USA

Competing Interests: No competing interests were disclosed.

The benefits of publishing with F1000Research:

- Your article is published within days, with no editorial bias

- You can publish traditional articles, null/negative results, case reports, data notes and more

- The peer review process is transparent and collaborative

- Your article is indexed in PubMed after passing peer review

- Dedicated customer support at every stage

For pre-submission enquiries, contact research@f1000.com 